\title{
Motivation to Study in Higher Education: A Comparison between Germany and Great Britain
}

\section{SANDRA LOEBER and HELEN E. HIGSON}

This article deals with reasons for the motivation to study in higher education. To find out about motives, around 200 A-level students in Germany and Great Britain were asked about their plans for the time after completion of their A-levels. Through socio-demographic data the authors could deploy facts about social backgrounds and the affiliations to socio-economic classes. There are some expected findings (e.g., British A-level students are more likely to study than their German comrades) and some pretty unexpected results (e.g., social classes do not seem to divide students into choosing university or not).

\section{Introduction}

The primary intention and the purpose of this article is to explain associations between the decision to study and other variables like gender or social background, but it is also about the reasons and influencing factors for school students choosing to go to study at university. In order to base data for a comparison between Germany and Great Britain upon an equal basis the authors created an ad hoc survey, which was carried out in a British secondary school and a German equivalent, a Gymnasium. The survey was based on six hypotheses and two research questions: Hypothesis one was about the likelihood of British and German A-level students studying at university: British A-level students are more likely to go to university than German A-level students. Hypothesis two was separated into a German part: Gender does not have an effect on whether or not someone chooses to go to university; and a British part: Gender has an effect on whether or not someone chooses to go to university. Hypothesis three was about the performance of A-level students: Above-average school students are more likely to study at university than below-average school students. Hypothesis four was about the effect of tuition fees: Tuition fees have a negative effect on whether or not someone goes to university. Hypothesis five implied the parental influence: Pupils who have parents who went to university are more likely to go to university than pupils who have parents who are non-academics. Hypothesis six was about the social background of A-level students: School students from a higher social background, as defined by parental socio-economic class, are more likely to study at university than other school students. 
The research questions were: (1) What influences the motivation to study most?; and (2) What are the most important reasons for going to university?

\section{Some Institutional Facts}

To introduce the reader to the topic it is necessary to provide some facts about the British and German tertiary education sectors.

\section{Higher Education Systems}

To equalize information about school systems the authors used the ISCED of $1997^{1}$ (UNESCO, 1997), in which seven levels of education are presented - from 0 to 6. For this article the researchers are only interested in the levels of higher education, i.e., once school studies are finished, which are levels ISCED 5, including for Germany the degrees of Diplom, Magister and Staatsexamen as well as Bachelor and Master's degrees in Great Britain (Organization for Economic Cooperation and Development [OECD] 2006b, p. 12) and ISCED 6, doctoral degree or PhD (OECD, 2006a, "Introduction").

Tuition Fees and Students' Allowance

For many years students in Germany did not pay tuition fees for their studies. Students had to pay a so called Semesterbeitrag, which included social contributions and an administration fee for student facilities though (OECD, 2004, p. 33). The amount of that contribution varied and still varies from institution to institution, but can be considered as small. This system has changed since autumn 2007 and will continue to change during the next couple of years. It is, therefore, likely that students pay or will have to pay tuition fees in addition to the Semesterbeitrag. Fees differ in form and amount between federal states. By winter term 2007-08, half of the federal states implemented general tuition fees which are mainly about $€ 500$ per semester (Deutsches Studentenwerk, 2007). Additionally, approximately two-thirds of the federal states implemented tuition fees for long-term students over the past years. Those fees range from approximately $€ 500$ to $€ 650$ per semester once students have exceeded a given number of semesters (Deutsches Studentenwerk, 2007). Up to now, students could receive financial support in the form of a federal training assistance (through BAföG), which is in general related to the parents' income, or an educational loan (Bildungskredit) from the KfW (Kreditanstalt für Wiederaufbau) (OECD, 2004, p. 33). Since tuition fees were

\footnotetext{
${ }^{1}$ International Standard Classification of Education 1997
} 
implemented critics have raised the issue that there are no suitable bursary or scholar- ship systems in Germany (Spiegel Online, 2006).

Undergraduate and postgraduate students in Great Britain have been obliged to pay tuition fees for a long time already (Clark, 2006, p. 15). Fees are divided into fees for UK and most EU students (called home fees) and fees for other foreign students (called overseas fees) (European Commission, 2006b). The level of undergraduate fees is influenced by the government that set a maximum limit for it. In 1998 higher education home fees for full time undergraduates were set to a maximum of $£ 1000$ per year (Clark, 2006, p. 15). But for study beginners in the academic year 2007-08 the costs of tuition fee for UK and EU students can be considered between $£ 0$ and $£ 3070$ per year and for 2008/2009 the maximum amount will raise up to $£ 3145$ per year (Directgov, n.d.). Each higher education institution decides the level of their tuition fees, although most institutions have set their fees at the highest level. Students do not have to pay fees while they are studying and are allowed to pay them back through the tax system as soon as they begin earning more than $£ 15,000$ per year (Department for Education and Skills [DfES], 2003, p. 76 et seq.). In addition, students' actual level of payment is related to parental income (Clark, 2006, p. 15). The British government demands that each university has a scheme of support like student loans, supplementary grants, mandatory awards, funds or bursaries available (European Commission, 2006b).

\section{Studies and Degree Structure}

So far higher education studies in Germany have been divided into a first phase (Grundstudium) and a second phase (Hauptstudium). The first phase usually takes about four semesters at university and terminates with an intermediate examination, the Vordiplom. The second phase in general ends after eight to ten semesters (including the first phase) with final degree examinations (OECD, 2004, p. 32). Up to now the most common academic degrees in Germany are as follows (European Commission, 2006a):

- Diplom degree (Diplomgrad);

- Magister degree (Magistergrad);

- State examination (Staatsexamen);

- Doctoral degree (Doktorgrad).

Since a revision of the Framework Law on Higher Education (Hochschulrahmengesetz) in 
1998, it is also possible to graduate with the Bachelor's or Master's degree in some institutions. The Bachelor's degree is the basis for entering Master's study. "The Master's Degree is the equivalent of the Diplom or Magister" (European Commission, 2006a). With the advent of the Bologna Process this development is being promoted. The implementation of Bachelor's and Master's degrees extends, but does not fully replace the old system of Diplom and Magister at present. By 2010 the two-phased system of Bachelor's and Master's degrees shall be generally implemented all over Germany (Statistisches Bundesamt, 2005, p. $1)$.

In Great Britain the majority of universities offer research opportunities and an extensive variety of courses at undergraduate and postgraduate levels (European Commission, 2006b). According to the European Commission fact sheet, "undergraduate courses for a first degree lead to the final qualification of a Bachelor degree" (European Commission, 2006b). To reach the final stage of an undergraduate study students in general have to study for three years (European Commission, 2006b). For certain subjects or special courses like sandwich courses, i.e. including a placement year, it can be longer. After successful graduation from a Bachelor it is possible to complete the following degrees (European Commission, 2006b):

- Master's degrees;

- Doctorates.

Master's degrees typically involve one year of full time studying at a higher education institution (European Commission, 2006b).

\section{Survey in German and British Secondary Schools to Create a Suitable Database}

\section{Methodology}

The investigators used the non-probability sampling method for this research. The aim of nonprobability sampling is not necessarily choosing a statistically representative sample of the target population (Hair et al., 2007, p. 181). Researchers deploy subjective approaches to pick sample elements. Such subjective methods can include personal experiences, a referral, some kind of judgement by experts or the researchers themselves, a quota or convenience (Hair et al., 2007, p. 181). As there are no statistical possibilities of measuring sampling errors (Hair et 
al., 2007, p. 181), sample data cannot be used with accuracy to generalize the target population, which is - as explained slightly more detailed later on in this paragraph - not an intention of the investigators within this work. The method, therefore, is very suitable for this research. Findings can still be utilized to describe, discover or even develop a theory, but only for the investigated sample (Hair et al., 2007, p. 170). Non-probability sampling might, however, be useful and a favourite method in some cases (Hair et al., 2007, p. 181). In this work the researchers used convenience sampling, which is basically described as "selecting sample elements that are most readily available to participate in the study and who can provide information required" (Hair et al., 2007, p. 181) quickly and cost efficiently (Hair et al., 2007, p. 181). For exactly these reasons (rapidity of the preparation of data and cost efficiency) the authors chose the convenience sampling method. There are some disadvantages of this method, which cannot be hidden. Convenience sampling suffers from bias in selection as the respondents of a survey can be dissimilar to the target population (Hair et al., 2007, p. 181). Hence it is complicated, if not risky, to generalize the results to the target population. Being aware of those difficulties, the researchers do not claim generalization or representativeness of any findings of the survey, but will compare the chosen samples and derive possible strategies, which may also be useful for the target population itself. Within this research project it would not have been possible to assure the complexity of a representative survey. To gather representative results it is necessary to undertake continuative studies and investigations.

\section{Data Collection ${ }^{2}$}

As the basis of the target population within this project was approximately 400 pupils, personal interviews would not have been possible owing to cost and time limitations. Therefore, it was more suitable for the researchers to choose a self-completion questionnaire as the most suitable instrument for the investigation. The researchers still had to bear in mind that respondents of the survey are aware that their behaviour or their attitudes will be investigated within the questionnaire and therefore answers may be influenced (Hair et al., 2007, p. 204).

\footnotetext{
${ }^{2}$ For primary data collection one has to distinguish qualitative (i.e., exploratory) and quantitative (i.e., descriptive or causal) collection of data. Whereas qualitative data are usually collected through interviews or observations for a smaller group, quantitative data are typically collected through self-completion or interviewercompleted surveys or observations for a rather large amount of participants with the help of large-scale surveys or even electronic databases (Hair et al., 2007, p. 192 et seq.).
} 


\section{Objectives}

The purpose of the study was not to establish exact rates of study enrolment. Rather it was about discovering associations between the decision to study and other variables like gender or social background. Furthermore, it was also concerned with the reasons and influencing factors for school students choosing to go to study at university. Therefore, the authors produced the six hypotheses mentioned before and two research questions from previous literature.

\section{Research Findings}

Again, all results are only relevant to the sample. As the sample cannot be considered representative findings cannot be generalized. By referring to Germany or Great Britain in this article it is based on the survey samples only.

Which method for bivariate inferential analyses is the most suitable method depends on the underlying type of scales of the variables. Accordingly, in testing Hypotheses 1 to 4, which dealt with dichotomous, nominal data, the researchers decided to carry out cross-tabulations (Diekmann, 1999, p. 584 et seq.). With Chi-square tests (in this study Pearson's Chi-square was used) one can accomplish statistical levels of significance (p) to explore associations or differences between variables within cross tabulations. The experimental hypothesis is thereby always that the variables are not independent of each other (Brace et al., 2006, p. 114) so the null hypothesis is about the independence of variables. In case of an indicated association Phi-coefficient, the symmetrical measure of correlation (Diekmann, 1999, p. 576), and Phi-square were calculated and analyzed to test the strength of association (Brace et al., 2006, p. 123 et seq.).

\section{Hypothesis 1: British A-level students are more likely to go to university than German A- level students.}

The null hypothesis of the independence of the variables ('decision to study' and 'country') has to be rejected. The relationship between the decision to study and the country was significant: Chi-square $(\mathrm{df}=1, \mathrm{n}=212)=26.396, \mathrm{p}=0.00$. The association can be considered as strong $(\mathrm{Phi}=0.330)$ (Universität Koblenz-Landau, Institut für Sozialwissenschaften, Abteilung Wirtschaftswissenschaft, 2007) and therefore the country accounted for 10.9 per cent (Phi-square $=0.1089$ ) of the variance in score on the study decision. Therefore, Hypothesis 1 can be accepted. In Great Britain 73.3 per cent of the Alevel students are going to study at university, whereas in Germany only 40.5 per cent of them 
are going to do so.

Hypothesis 2: Germany: Gender does not have an effect on whether or not someone chooses to go to university. Great Britain: Gender has an effect on whether or not someone chooses to go to university.

For Germany the null hypothesis of the independence of the variables ('decision to study' and 'gender') can be accepted. There was no relationship between the decision to study and the gender: Chi-square $(\mathrm{df}=1, \mathrm{n}=126)=1.794, \mathrm{p}=0.180$. Therefore, Hypothesis 2 can be accepted for Germany. The observed greater rate (62.7 per cent) of females going to university versus 37.3 per cent of males appeared by chance only. That is why we have to consider male and female pupils who decided to go to university equally after completion of A-levels in Germany.

For Great Britain the null hypothesis of the independence of the variables ('decision to study' and 'gender') has to be rejected. The relationship between the decision to study and gender was significant: Chi-square $(\mathrm{df}=1, \mathrm{n}=115)=6.511, \mathrm{p}=0.011$. The association was of moderate strength (Phi $=0.238)$ (Universität Koblenz-Landau, Institut für Sozialwissenschaften, Abteilung Wirtschaftswissenschaft, 2007) and therefore the gender accounted for 5.7 per cent (Phi-square $=0.05664$ ) of the variance in score on the study decision. Therefore, Hypothesis 2 can be accepted for Great Britain. The observed greater rate of females (63.5 per cent) who want to go to university versus 36.5 per cent of males was significant.

Hypothesis 3: Above-average school students are more likely to Study at university than below-average school students.

For Germany the null hypothesis of the independence of the variables ('decision to study' and 'above- or below-average grades') can be accepted. The relationship between the decision to study and the grades was not significant: Chi-square $(\mathrm{df}=1, \mathrm{n}=120)=0.653, \mathrm{p}=0.419$. Therefore, Hypothesis 3 has to be rejected for Germany. The observed greater percentage (59.6 per cent) of above-average pupils going to university versus 40.4 per cent of belowaverage pupils appeared randomly.

For Great Britain the null hypothesis of the independence of the variables ('decision to study' and 'above- or below-average grades') has to be rejected. The relationship between the 
decision to study and the grades was significant: Chi-square $(\mathrm{df}=1, \mathrm{n}=93)=7.237, \mathrm{p}=$ 0.007. The association was of moderate strength $(\mathrm{Phi}=0.279)$ (Universität Koblenz-Landau, Institut für Sozialwissenschaften, Abteilung Wirtschaftswissenschaft, 2007) and, therefore, the mean grades account for 7.8 per cent $($ Phi-square $=0.077841)$ of the variance in score on the study decision. Therefore, Hypothesis 3 can be accepted for Great Britain. The observation showed 60.8 per cent above-average versus 39.2 per cent below-average pupils are going to university.

\section{Hypothesis 4: Tuition Fees Have a Negative Effect on Whether or Not someone goes to university.}

For Germany the null hypothesis of the independence of the variables ('decision to study' and 'tuition fees') can be accepted. There was no relationship between the decision to study and tuition fees: Chi-square $(\mathrm{df}=1, \mathrm{n}=98)=0.529, \mathrm{p}=0.467$.

Therefore Hypothesis 4 has to be rejected for Germany. The following observation only occurred by chance: 40.4 per cent of school students who intend to go to university said they had to think twice about their decision versus 59.6 per cent of them who said they did not have to think twice about their study decision. Furthermore, 33.3 per cent of school students who did not intend to go to university said they were put off by tuition fees from going to university versus 66.7 per cent of them who said they were not put off by tuition fees from going to university.

For Great Britain the analysis showed that one cell had expected to count less than 5 , so an exact significance test was selected for Pearson's Chi-square. The null hypothesis of the independence of the variables ('decision to study' and 'tuition fees') can be accepted. There was no relationship between decision to study and tuition fees: Chi-square $(\mathrm{df}=1, \mathrm{n}=87)=$ 0.581 , exact $\mathrm{p}=0.536$. Therefore, Hypothesis 4 also has to be rejected for Great Britain. This observation only randomly occurred: 33.8 per cent of school students who intend to go to university said they had to think twice about their decision versus 66.2 per cent of them who said they did not have to think twice about their study decision. Furthermore, 23.1 per cent of school students who did not intend to go to university said they were put off by tuition fees from going to university versus 76.9 per cent of them said they were not put off by tuition fees to go to university.

In investigating Hypothesis 5 and 6 the researchers wanted to measure the degree of a 
relationship between two variables, so the most appropriate method seemed a correlation of the variables (Brace et al., 2006, p. 94). As the variables (besides 'decision to study' there is for Hypothesis 5 'mean qualifications of parents' and for Hypothesis 6 'socio-economic class of parents') are supposed to be ordinal variables the correlation coefficient Kendall's tau-b and the level of significance were tested (Brosius, 2007, p. 245). So the tested correlations were non-parametric correlations (Brace et al., 2006, p. 106). "A correlation coefficient allows us to estimate the proportion of variation within our data that is explained by the relationship between two variables" (Brace et al., 2006, p. 105). Correlation coefficients can only disclose linear associations (Brosius, 2007, p. 253).

Hypothesis 5: Pupils who have parents who went to university are more likely to go to university than pupils who have parents who are non-academics.

For Germany there was a significant positive correlation between the decision to study and the mean level of parental education (Kendall's tau-b $=0.213, \mathrm{n}=116, \mathrm{p}=0.09$, two-tailed), although the correlation is only of weak strength. Therefore, Hypothesis 5 can be accepted for Germany: As the mean level of parental education increases, there is a greater chance that the pupil will decide to study at university.

For Great Britain there was no such significant correlation between the decision to study and the mean level of parental education (Kendall's tau-b $=0.136, n=90, p=0.139$, two-tailed). Therefore, Hypothesis 5 cannot be accepted for Great Britain. It has to be rejected.

Hypothesis 6: School students from a higher social background, as defined by parental socio-economic class, are more likely to study at university than other school students.

For Germany there was no significant correlation between the decision to study and the parental socio-economic class (Kendall's tau-b $=0.004, \mathrm{n}=126, \mathrm{p}=0.961$, two-tailed). Therefore, Hypothesis 6 has to be rejected for Germany.

For Great Britain there was also no significant correlation between the decision to study and the parental socio-economic class (Kendall's tau-b $=0.092, n=116, p=0.296$, two-tailed). Therefore, Hypothesis 6 has to be rejected for Great Britain.

To answer Research Questions 1 and 2 the influencing factors (Research Question 1) and the reasons (Research Question 2) were initially subject to an exploratory factor analysis. This 
was in order to reduce data and receive more meaningful factors (instead of using all given items) for the subsequent analysis (Brace et al., 2006, p. 303). The researchers decided to use a multiple linear regression to find corresponding results for research questions 1 and 2. "A multiple regression is a statistical technique that allows... to predict someone's score on one variable on the basis of their scores on several other variables" (Brace et al., 2006, p. 228). The criterion variable ('going to study at university') is predicted with the help of the predictor variables (in this case the calculated factors as explained before) (IZHD, n.d.). The predictor variables were measured with the help of a five-point Likert scale. So, strictly speaking, they do not meet the requirements of a linear regression as they are not truly interval data, but are rather commonly used in multiple linear regression analyses (Katz, 2006, p. 28). With the help of multiple regressions it is possible to estimate the likeliness of the occurrence of the criterion by identification of a group of predictors (Brace et al., 2006, p. 228).

\section{Research question 1: What influences the motivation to study most?}

To reduce the number of variables, the variables were analyzed by means of a factor analysis using a principal component method, with a varimax rotation. The indicators of factorability (Kaiser-Meyer-Olkin Measure of Sampling Adequacy [KMO] $=0.679$ and Bartlett's Test of Sphericity, $\mathrm{p}=0.00$ ) were evaluated as good. Three components were revealed with an Eigenvalue greater than 1.0, those were also exposed within a scree plot. With the help of the component matrix the researchers could see that the components, i.e. factors, can be described as groups of influencing factors for going to university. The names chosen for the components are: Component 1 'people and services'; Component 2 'other'; and Component 3 'nonpersonal information tools'. A linear regression using the enter method was accomplished with these factors. For Germany, a significant model emerged that analysis (ANOVA: F = 187.968, $\mathrm{df}=3, \mathrm{p}=0.00$ ). The predictors are able to explain 94.1 per cent (adjusted $\mathrm{R}$-square $=0.941$ ) of the criterion 'going to university'. The non-standardized coefficient B shows the predicted increase in the criterion value for a one-unit-increase in the particular predic- tor (Brace et al., 2006, p. 239). The standardized Beta ( $\beta$ ) measures the contribution of each variable to the model in terms of standard deviation. According to that, $\beta$ is the prophesied change in standard deviation of the criterion for a modification of one standard deviation in the predictor (Brace et al., 2006, p. 239). The value of $\beta$ can be interpreted as relative importance of the particular variable (Leibniz Rechenzentrum der Bayrischen Akademie der Wissenschaften, 2005, p. 11). The significance shows for all predictors a value $\mathrm{p}<0.05$ so all 
predictors can be considered significant. "The tolerance values are a measure of the correlation between the predictor variables and can vary between 0 and 1" (Brace et al., 2006, p. 240). As all predictors' tolerance is greater than 0.01 these values can be considered as good (Brace et al., 2006, p. 240). Summarizing the 'non-personal information tools' can be considered as the most influential source of information German school students acquire if they want to go to university.

For Great Britain, the same method of linear regression also emerged a significant model (ANOVA: $\mathrm{F}=164.388, \mathrm{df}=3, \mathrm{p}=0.00$ ). The predictors are able to explain 95.5 per cent (adjusted R-square $=0.955$ ) of the criterion variable 'going to university'. 'People and services' was a significant predictor, while the other two were not. As all predictors' tolerance is greater than 0.01 these values can be considered as good (Brace et al., 2006, p. 240). Summarizing the factor 'people and services' can be considered as the most influential source of information British school students acquire if they want to go to university.

\section{Research Question 2. What are the most important reasons for going to university?}

To reduce the number of variables, the variables were analyzed by means of another factor analysis using the principal component method, with a varimax rotation. While including all variables into this factor analysis the factorability $(\mathrm{KMO}=0.573)$ was only poor. For that reason the researchers decided to remove the poorly valued variable 'other' and rerun the analysis. This time factorability $(\mathrm{KMO}=0.691$ and Bartlett's Test of Sphericity $\mathrm{p}=0.00)$ was assessed as good. Three components were revealed with an Eigenvalue greater 1.0, those were also exposed within a scree plot. With the help of the component matrix the researchers could see the three groups of components, which all identify reasons for going to university. The names chosen for the components are: Component 1 'job-related reasons'; Component 2 'reasons referring to the person itself'; and Component 3 'continuative education or insecurity about job'. A linear regression using the enter method was accomplished with these factors. For Germany, a significant model emerged that analysis (ANOVA: $\mathrm{F}=821.559$, df $=3, \mathrm{p}=$ 0.00). The predictors are able to explain 98.3 per cent (adjusted R-square $=0.983$ ) of the criterion 'going to university'. All predictors were significant. As all predictors tolerance is greater than 0.01 these values can be considered as good (Brace et al., 2006, p. 240). Summarizing, 'reasons referring to the person itself' can be considered as the most important reasons for German school students to choose to go to university. 
For Great Britain, the same method of linear regression also produced a significant model (ANOVA: $\mathrm{F}=1457.873$, df $=3, \mathrm{p}=0.00$ ). The predictors explain 98.4 per cent (adjusted Rsquare $=0.984)$ of the criterion 'going to university'. All predictors were significant. As all predictors' tolerance is greater than 0.01 these values can be considered as good (Brace et al., 2006, p. 240). Summarizing, 'reasons referring to the person itself' can also be considered as the most important reasons for British school students to choose to go to university.

\section{Conclusion}

Four major conclusions can be drawn from the study. Firstly, findings clearly confirm the lower enrolment rates of German young people, contrary to their British counter- parts. In fact, Germany has to keep improving its study system and conditions to compete with the education in other developed nations.

The second major conclusion is that gender really does not seem an issue. Indeed, females did not only keep up with male rates of students (in Germany), but also partly overhauled those (in Great Britain).

Thirdly, tuition fees seem not to have a correlation with the motivation to study. In fact (however, not significant) results even show that school students in both Germany and Great Britain do not seem overly concerned with tuition fees, neither do these fees seem to put them off from going to study at university. As in Great Britain tuition fees have been in place for a number of years, Germany could possibly have a closer look at its neighbouring country and maybe get some good ideas or guidelines for its own legislation in this subject.

And the fourth major conclusion is about the relation between the social background of pupils and their decision to study at university. Social class affiliation does not seem an influencing factor anymore. This may be because it is very difficult to separate socio-economic classes, but it may also be that parental socio-economic class does not influence their children's decision too much anymore as, for example, there are independent ways of financing studies.

\section{Limitations and Recommendations for Further Research}

First of all, the study is a non-experimental study, i.e., conditions within the survey are not modified to find out about any causation. Within this study it is only possible to show 
connection and differences between variables.

Due to limited time and cost conditions the study is based on convenience sampling of the target population. For this reason any findings have to be treated carefully and cannot be announced as representative.

Despite all precautions, a possible defect of the instrument that was used in the survey is that within a self-completion questionnaire survey participants can be concerned how their answers appear to the researchers. It is, therefore, possible that participants had answered dishonestly or in a socially desirable way.

Another flaw could also be that in Great Britain only 30 per cent of the participants were studying in the last year of A-levels. That means the majority of them were still in the penultimate year, which could cause bias in the answers as they might not know definitely what they are going to do after school and only assuming their own decisions. The allocation between penultimate and final year was rather balanced in Germany.

An additional limitation of the survey is that it only used school students themselves and, therefore, data about the occupation and qualification of the parents can be distorted or simply wrong, as children might not know exact data about their parents' professions and qualifications.

Owing to the limitations given earlier, it would be good to carry out a larger investigation with a representative sample size to confirm findings in general. It can also be useful to interview pupils from different types of schools such as private or state secondary schools in Great Britain and general educating (Allgemeinbildendes Gymnasium) or economic (Wirtschaftsgymnasium) secondary schools in Germany.

Regarding the profession and the qualification of the parents it might be constructive to involve parents in the survey and let them answer questions about their qualifications, apprenticeships, studies and occupations themselves. This would mean that the researchers will receive much more reliable data.

For further research it should also be taken into account that working with minors always needs particular care and protection. Within this study the researchers had to go through a long and demanding procedure to receive permission to carry out the survey. 


\section{References}

BRACE, N., KEMP, R. and SNELGAR, R. SPSS for Psychologists (3rd edition). Basingstoke: Lawrence Erlbaum Associates, 2006.

BROSIUS, F. SPSS für Dummies [SPSS for Dummies]. Weinheim: Wiley-VCH, 2007.

CLARK, T. "OECD Thematic Review of Tertiary Education - Country Report: United Kingdom".

Retrieved on 10 April 2007, from <http://www.oecd.org/dataoecd/22/3/37211152.pdf〉, 2006.

DEUTSCHES STUDENTENWERK. "Übersicht: Studiengebühren in den 16 Bundesländern” [Overview: Tuition fess within the 16 Federal States]. Retrieved on 4 April 2007, from $<$ http://

www.studentenwerke.de/pdf/Uebersicht\%20Details\%20Studiengebuehren.pdf>, 2007.

DFES. "The Future of Higher Education". Retrieved on 4 April 2007, from <http:// www.dfes.gov.uk/hegateway/uploads/White\%20Pape.pdf>, 2003.

DIEKMANN, A. Empirische Sozialforschung, Grundlagen, Methoden, Anwendungen [Empirical Social Research, Basics, Methods, Uses] (5th edition). Reinbek, Germany: Rowohlt-Taschenbuchverlag, 1999.

DIRECTGOV. "How Much Will University Cost Tuition Fees and Other Expenses". $\begin{array}{lllll}\text { Retrieved } & \text { on } & 3 & \text { May } & \text { 2008, from }\end{array}$ <http://www.direct.gov.uk/en/EducationAndLearning/UniversityAndHigherEducation/StudentFinance/FinanceForNewStudents/DG_10034860>,n.d.

EUROPEAN COMMISSION. "Education and Study - Higher School (Germany)". Retrieved on 4 April 2007, from <http://ec.europa.eu/youreurope/nav/en/citizens/educationstudy/higher-school/de/index_en.html\#1483_12>, 2006a.

EUROPEAN COMMISSION. "Education and Study - Higher School (United Kingdom)". Retrieved on 4 April 2007, from <http://ec.europa.eu/youreurope/nav/en/citizens/education- 
study/higher-school/uk/index_en.html>, 2006b.

HAIR, J., MONEY, A., PAGE, M. and SAMOUEL, P. Research Methods for Business. West Sussex: John Wiley \& Sons (UK), 2007.

IZHD, ed. "LernStats, Glossar" [LearnStats, Glossary]. Retrieved on 23 May 2007, from <http:/ /www.lernstats.de/web/php/glossar.php>, n.d.

KATZ, M.H. Multivariable Analysis, A Practical Guide for Clinicians (2nd edition). Cambridge: Cambridge University Press, 2006.

LEIBNIZ RECHENZENTRUM DER BAYRISCHEN AKADEMIE DER WISSENSCHAFTEN. "SPSS Special Topics: Lineare Regression 6/2005” [SPSS Special Topics: Linear Regression 6/2005]. Retrieved on 13 May 2007, from <http://www.lrzmuenchen.de/services/schulung/unterlagen/ regression>, 2005.

OECD. "Survey of Higher Education Systems". Retrieved on 15 January 2007, from <http:// www.oecd.org/dataoecd/41/59/32503573.PDF>, 2004.

OECD. "Background Report on Higher Education: Quality, Equity and Efficiency". Retrieved on 2 April 2007, from <http://www.oecd.org/dataoecd/30/7/36960580.pdf>, 2006a.

OECD. "Education at a Glance 2006 - OECD Briefing Note for the United Kingdom". Retrieved on 10 April 2007, from <http://www.oecd.org/dataoecd/32/50/37392956.pdf>, $2006 b$.

SPIEGEL ONLINE. "Fehlende Stipendien sind ein Skandal" [Missing scholarships are $\begin{array}{lllll}\text { outrageous]. } & \text { Retrieved } & \text { on } & \text { November }\end{array}$ <http://www.spiegel.de/unispiegel/studium/ 0,1518,443297,00.html>, 2006.

STATISTISCHES BUNDESAMT. "Pressekonferenz 'Hochschulstandort Deutschland 2005' am 6 Dezember 2005 in Berlin, Statement von Präsident Johann Hahlen” [Press Conference "Germany as A Location for Higher Education 2005" on 6 December 2005 in Berlin, Statement of the President Johann Hahlen]. Retrieved on 9 April 2007, from 
<http://www.destatis.de/ presse/deutsch/pk/2005/Statement_Hahlen_Hochschulstandort.pdf>, 2005.

UNESCO. "International Standard Classification of Education ISCED 1997”. Retrieved on 2 April 2007, from <http://www.unesco.org/education/information/nfsunesco/doc/isced_1997. htm>, 1997.

UNIVERSITÄT KOBLENZ-LANDAU, INSTITUT FÜR SOZIALWISSENSCHAFTEN, ABTEILUNG WIRTSCHAFTSWISSENSCHAFT. "Übersicht über Zusammenhangsmaße" [Overview of Measures of Associations]. Retrieved on 9 June 2007, from <http://iww.unilandau.de/unterlagen/SS07/somaggio/ueb-statistik/uebersicht_Syntax-Befehle.pdf>, 2007. 